\title{
READABILITY OF CORPORATE REPORTS AND IMPRESSION MANAGEMENT
}

\author{
DOI: 10.17261/Pressacademia.2018.902 \\ PAP- V.7-2018(55)-p.300-302
}

\section{Arzu Ozsozgun Caliskan¹, Emel Esen²}

${ }^{1}$ Yildiz Technical University, Faculty of Economics and Administrative Sciences, Davutpasa Campus, Istanbul, Turkey. aozsozgun@yildiz.edu.tr, ORCID: 0000-0001-5753-3252

${ }^{2}{ }^{2}$ Ildız Technical University, Faculty of Economics and Administrative Sciences, Davutpasa Campus, Istanbul, Turkey. emeloz@yildiz.edu.tr, ORCID: 0000-0001-6209-4952

To cite this document

Ozsozgun, C. A. Esen, E. (2018). Readability of corporate reports and impression management. PressAcademia Procedia (PAP), V.7, p.300302.

Permemant link to this document: http://doi.org/10.17261/Pressacademia.2018.902

Copyright: Published by PressAcademia and limited licenced re-use rights only.

\section{ABSTRACT}

Purpose- Understanding the disclosed information about the company is necessary for decision-making. Prior research shows that companies could use different writing style to obscure negative information. The main aim of the paper is to review readability measures and to understand how readability of corporate reports could be used as a tool for impression management.

Methodology- The literature is rewived to find out the readability measures and to understand how readability of corporate reports could be used as a tool for impression management.

Findings- It is found that different readability formulas are developed in the literature. The most common readability formulas are developed on text in English. However, there are different readability measures in different language.

Conclusion- To disclose corporate information in readable form is necessary condition for stakeholders' their decision making process. In addition, corporation could use readability of disclosed information for their impression management.

Keywords: Corporate reporting, readability, impression management, corporate disclosure, narrative disclosure language. JEL Codes: M10, M40

\section{INTRODUCTION}

Corporate reports are an important input in decision making for investors, regulators and the broader community. Especially publicly traded companies are required to produce public documents that provide comprehensive information about their firm performance and financial position that is not provided by other means (Chung et al., 2016). Understanding the disclosed information about the company is necessary for decision-making. For that reason, it is hence imperative for corporations to compose the corporate reports in a clear and readable way. Research results show that firms with more complicated annual reports have lower earnings persistence when they are profitable. There is a clear correlation between the linguistic features of annual reports and firm performance (Li, 2008). However, it could be diffcult to define the meaning of readability and to measure it (Loughran and McDonald, 2014). Readability is about how easy or difficult it is to read, to understand a written material and is defined by Klare as the ease of understanding or comprehension due to the style of writing (Dolnicar and Chapple, 2015).

Corporate reports could be a medium to influence public perception and communicate with their stakeholders. Organizations use impression management tactics to manage their reputation and enhance a positive image to their stakeholders (Terrell and Kwok, 2011). Organizational impression management is defined as "any action purposely designed and carried out to influence an audience's perceptions of an organization" (Tyler et al., 2012, 336). The motivation behind impression management is the desire to achieve a specific public perception or to correct differences of what is perceived by the public with what is desired to be perceived. The disclosure of corporate information serves to facilitate the projection of an accountable image. This will lead to increased legitimacy and will allow the company to manage reputational risks.

For this perspective, we first discuss the readability of corporate reports and impression management at organizational level, then we make some suggestions for further studies. 


\section{LITERATURE REVIEW}

Readability refers to how easily written materials can be read and understood and it depends on many factors, including the average length of sentences in a passage, the number of new words a passage contains, the grammatical complexity of the language used (Richards, et al. 1992). It is generally confused with legibility, which concerns typeface and layout (Fakhfakh, 2016). To promote readability in corporate reports, regulators and professional accounting organizations took specific steps to improve readability and understandability of financial disclosures. For that purpose, The Securities and Exchange Commission (SEC) adopted Plain English Mandate in 1998 and provided a companion handbook entitled "A Plain English Handbook; How to create clear SEC disclosure documents". In 2013, the American Institute of Certified Public Accountants (AICPA) launched the Center for Plain English Accounting to help auditors and practitioners to more clearly explain the technical accounting literature to their clients by providing plain English interpretations (Bonsall IV, et al., 2014). "Plain English is clear, direct, and simple; but good plain English has both clarity and grace" (Xanthaki, 2010).

In the 1920s, educators discovered a way to use vocabulary difficulty and sentence length to predict the difficulty level of a text. They embedded this method in readability formulas and the formulas were used in journalism, research, health care, law, insurance, industry and military (DuBay, 2004). Readability formulas try to provide an objective prediction of text difficulty. There are many readability formulas in the literature. However, The Flesch Reading Ease Score, The Fog Index, The Flesch-Kincaid Grade Level score and The Gunning Fog Index are the most well-know nfor English language (Horner, 2000). Although, there are differences between the formulas, there are some common element in them, such as sentence length, number of syllables.

Since every language has different properties of its expressions, it could not be possible to use one measure for different language. Turkish is an agglutinating language applying the principle of stacking suffix to suffix. It is by means of morphology that Turkish marks grammatical processes such as case and number in nouns, tense, aspect and voice in verbs (Pembeci, et al., 2001). According to literature, the first readability formula for Turkish is developed by Ateşman. Ateşman (1997) adapted Flesch's formula to Turkish. This formula is based on the length of Turkish words and phrases and applied on a 100-word section selected from text. Uzun and Çetinkaya (2010) and Bezirci and Yilmaz (2010) also have developed Turkish readability formulas. To the best of our knowledge, the Turkish readability formula have been used to test Turkish school textbooks. On the other hand, it is possible to use these formulas to test the corporate reports.

In corporate reporting context, impression management is regarded as intending to influence audiences' perceptions of organizations performance (Brennan and Merkl-Davies, 2013). In addition to manipulating the presentation and content of disclosure, impression management can be reflected in the refusal to communicate by presenting minimal information or using complicated wording style (Leung, et al. 2015). Impression management in corporate reporting concept is an important research area. Because accounting narratives that used for impression management purposes may undermine the corporate reporting qualtiy and cause capital misallocations (Brennan and Merkl-Davies, 2013). Research on the readability of financial reports show that firms with more readable financial reports have more pronounced small investor trading, and in addition, that trading volume reactions increase with the readability of analysts' reports (Bonsall IV, et al., 2014). According to Li (2008) both less readable and longer reports are associated with lower profitability and lower earnings persistence and interprets this association as evidence of managerial obfuscation when performance is poor. On the other hand, readability is significantly higher for the firms where performance improves over the prior period rather than deteriorates (Asay, et al. 2018).

\section{DATA AND METHODOLOGY}

The study is theoretical to understand reability concept, its measures and how readability of corporate reports could be used as a tool for impression management.

\section{FINDINGS}

According to theoretical explanations, every language has different properties of its expressions, it could not be possible to use one measure for different language. For that reason, there is need to have different readability measure for different language. There are readability measures that developed to test dufficulty of Turkish.

Research results show that the linguistic characteristics of narrative disclosures vary with firm performance and intentional obfuscation of bad news may be a useful strategy for managers.

\section{CONCLUSION}

Readability and understandability is related to each other. Especially, it can be very difficult to understand financial information and the decision for the best option requires informed perspectives. For that reason, to disclose corporate information in readable form is necessary condition for stakeholders' their decision making process. In addition, corporation could use readability of disclosed information for their impression management, especially when firm performance is poor. Managers could provide less redable bad news reports when they have a reporting goal to portray the firm in a favourable light. Further studies can analyse the readability of corporate reports in Turkey and examine if the readability of reports are influced by corporations's performance or not. 


\section{REFERENCES}

Asay, H. S., Libby, R., Rennekamp, K. (2018). Firm performance, reporting goals, and language choices in narrative disclosures. Journal of Accounting and Economics.

Brennan, N. M., Merkl-Davies, D. M. (2013). Accounting narratives and impression management. The Routledge companion to accounting communication, 109.

Chung, D., Hrazdil, K. Suwanyangyuan, N. (2016). Disclosure quantity and the efficiency of price discovery: evidence from the Toronto Stock Exchange. Review of Accounting and Finance, 15 (2), p.122-143.

Leung, S., Parker, L., Courtis, J. (2015). Impression management through minimal narrative disclosure in annual reports. The British accounting review, 47(3), p. 275-289.

Ateşman, E. (1997). Türkçede okunabilirliğin ölçülmesi. Dil Dergisi, 58 (71-74).

Bonsall IV, S. B., Leone, A. J., Miller, B. P., Rennekamp, K. (2017). A plain English measure of financial reporting readability. Journal of Accounting and Economics, 63(2-3), 329-357.

Dolnicar, S., Chapple, A. (2015). The readability of articles in tourism journals. Annals of Tourism Research, 52, 161-166.

DuBay, W. H. (2004). The principles of readability. Accessed: June 25, 2018, from: https://files.eric.ed.gov/fulltext/ED490073.pdf,.

Fakhfakh, M. (2016). Linguistic performance and legibility of auditors' reports with modified opinions: an advanced investigation based on the ISAs on audit reports. Asian Review of Accounting, 24(1), 105-130.

Godfrey, J., Mather, P., Ramsay, A. (2003). Earnings and impression management in financial reports: the case of CEO changes. Abacus, 39(1), 95-123.

Horner, S. D., Surratt, D., Juliusson, S. (2000). Improving readability of patient education materials. Journal of community health nursing, 17(1), 15-23.

Li, F. (2008). Annual report readability, current earnings, and earnings persistence. Journal of Accounting and economics, 45(2-3), 221-247.

Loughran, T., McDonald, B. (2014). Measuring readability in financial disclosures. The Journal of Finance, 69(4), $1643-1671$.

Pembeci, I., Bozsahin, C., Zeyrek, D. (2001). Computer-assisted learning of Turkish morphology. Accessed: June 25, 2018, from: https://pdfs.semanticscholar.org/2208/3f900fce3c8267c4c7e0510c431cd4830ee8.pdf

Richards, J. C., Schmidt, R., Kendricks, H., Kim, Y. (2002). Longman dictionary of language teaching and applied linguistics. Third Edition. UK:Pearson Education Limited.

Terrell, K. H., Kwok, L. (2011). Organizational impression management behaviors in social media: a perspective of a social networking site. In 16th Graduate Student Research Conference in Hospitality and Tourism. en: http://works. bepress. com/linchi_kwok/1

Tyler, J. M., Connaughton, S. L., Desrayaud, N., Fedesco, H. N. (2012). Organizational impression management: utilizing anticipatory tactics. Basic and Applied Social Psychology, 34(4), 336-348.

Xanthaki, H. (2010). Drafting manuals and quality in legislation: positive contribution towards certainty in the law or impediment to the necessity for dynamism of rules?. Legisprudence, 4(2), 111-128. 